\title{
Plant Growth and Nutritional Quality Attributes of Basella alba Applied with Variable Rates of Nitrogen Fertilizer at Different Planting Dates under Canadian Maritime Climatic Conditions
}

\author{
Nishchitha Hemmige Natesh $(\mathbb{D}$, Mercy O. Ijenyo $\mathbb{D}$, Samuel Kwaku Asiedu $(\mathbb{D}$, \\ H. P. Vasantha Rupasinghe $\mathbb{B}$, and Lord Abbey \\ Department of Plant, Food, and Environmental Sciences, Faculty of Agriculture, Dalhousie University, 50 Pictou Road, \\ Truro B2N 5E3, Nova Scotia, Canada \\ Correspondence should be addressed to Lord Abbey; labbey@dal.ca
}

Received 20 February 2021; Accepted 7 May 2021; Published 20 May 2021

Academic Editor: Othmane Merah

Copyright (c) 2021 Nishchitha Hemmige Natesh et al. This is an open access article distributed under the Creative Commons Attribution License, which permits unrestricted use, distribution, and reproduction in any medium, provided the original work is properly cited.

\begin{abstract}
Nitrogen $(\mathrm{N})$ fertilization at critical planting time is important to optimize productivity and reduce nitrate accumulation in edible portions of green leafy vegetable plants. A field experiment was performed to determine the effects of variations in $\mathrm{N}$ rate and planting time on plant growth, yield, and nutritional quality attributes of Basella alba under Atlantic maritime climatic conditions. The $\mathrm{N}$ rates were 0 (control), 40 (low), 80 (medium), and $120 \mathrm{~kg} \mathrm{ha}^{-1}$ (high) at planting times 15 June-3 August (early season), 6 July-20 August (mid-season), and 4 August-8 September (late season). Plant height, number of branches, and stem girth were increased after 45 days after sowing in early and mid-season plantings, but leaf length decreased during the same time by $32.8 \%$ in the late planting. The average yield obtained in early, mid-, and late plantings were 171,464 , and $328 \mathrm{~g}$ plant ${ }^{-1}$, respectively. Low $\mathrm{N}$ gave the highest yield in early planting while medium $\mathrm{N}$ gave higher yields in mid- and late plantings. However, the medium $\mathrm{N}$ increased nitrate accumulation in $B$. alba by $7 \%$ compared to the high $\mathrm{N}$ rate. In general, there was no significant effect of $\mathrm{N}$ on $B$. alba total phenolic and total carotenoid contents. Overall, the highest yield was obtained during the warmest summer months of mid- and late plantings. Therefore, there is a potential to grow $B$. alba as a summer vegetable under Canadian Atlantic maritime conditions. However, it is recommended to reduce the rate of $\mathrm{N}$ fertilizer application during high-temperature conditions. Future studies are required to investigate phosphorus and potassium fertilization and nitrate accumulation in $B$. alba and potential health risks.
\end{abstract}

\section{Introduction}

Basella alba L., also known as Malabar spinach, Indian spinach, vine spinach, and Ceylon spinach, belongs to the family Basellaceae. It is a leafy green, perennial-vined vegetable plant. B. alba is extensively grown in tropical Asia and Africa $[1,2]$. The other competitive species in the family is Basella rubra L. (red leaves and stems), which is typically grown for its greenness and rapid growth $[3,4]$ compared to $B$. alba (green leaves and stems) $[5,6]$. B. alba is a fairly popular tropical ethnic leafy vegetable among some group of immigrants in Ontario, Canada [7]. However, it is an undervalued Canadian ethnic vegetable with limited interest and acreage, which is mainly due to scanty information on the agronomic requirement and its culinary and nutritional importance.

Nitrogen $(\mathrm{N})$ fertilizer is a major requirement to produce green leafy vegetables and one of the major biochemical constituents in plant tissues [8]. Nitrogen is known to enhance the productivity and nutritional quality of green leafy vegetables $[9,10]$. The leafy part of $B$. alba is a rich source of antioxidants, polyphenols, carotenoids, vitamins A and C, 
folate, calcium, and potassium [11]. B. alba is also a valuable medicinal vegetable due to its gelatinous/mucilaginous substances, which is used for the treatment of constipation, mouth ulcers, and inflammations $[12,13]$. Despite the nutritional and health benefits associated with $B$. alba, field production is hampered by environmental and agronomic factors such as light, temperature, and pest $[7,14]$. Therefore, a valuable aspect of the production of $B$. alba under maritime conditions that must be taken into consideration is the influence of the growing season weather conditions. The growth performance and quality of a vast majority of green leafy vegetables including are dependent on the length of day and temperature [15]. For instance, the nutritional quality of leafy vegetables is reduced under low-light conditions [16]. Research showed that $\mathrm{N}$ availability to plants is influenced by seasonal weather conditions [17] and cold stress during growth, and this can affect the amounts of soluble sugars, vitamin C, and amino acids [18]. Usually, vegetables such as spinach (Spinacia oleracea) are grown as an early spring vegetable from early April to mid-April, and mid- to late August as fall vegetables under relatively stable cool-season temperature in Canada. Since it is of tropical origin, growing season differential temperature may influence the response pattern to $\mathrm{N}$ fertilizer but understudied. To the best of our knowledge, there is no published report on the best planting time in the maritime regions.

It is well known that $\mathrm{N}$ is critical in the production of leafy vegetables, and suboptimal $\mathrm{N}$ application rates have been shown to alter the concentrations of ascorbic acid and phenolic compounds [19]. However, there is limited documented information on the optimal $\mathrm{N}$ rate for under maritime conditions. $\mathrm{N}$ recommendations for spinach grown in Nova Scotia showed that between 70 and $90 \mathrm{~kg} \mathrm{~N}$ $\mathrm{ha}^{-1}$ is optimal for improved plant growth and yield [20]. A greenhouse study in the Netherlands [14] reported an increase in stem length of $B$. alba at four weeks after transplanting with the application of $90 \mathrm{~kg} \mathrm{~N}^{-1}$ while either $90 \mathrm{~kg} \mathrm{~N} \mathrm{ha}{ }^{-1}$ or $120 \mathrm{~kg} \mathrm{~N} \mathrm{ha}^{-1}$ increased the number of leaves, green color, and fresh leaf yield.

The hypothesis is that a high $\mathrm{N}$ application rate $(120 \mathrm{~kg} \mathrm{~N}$ $\mathrm{ha}^{-1}$ ) and late planting time would result in the best growth, yield, and phytochemical quality of B. alba than low $(40 \mathrm{~kg} \mathrm{~N}$ $\left.\mathrm{ha}^{-1}\right)$ and medium rates $\left(80 \mathrm{~kg} \mathrm{~N} \mathrm{ha}^{-1}\right)$ and early season and mid-season planting times. Therefore, the objective of this study was to evaluate the effect of $\mathrm{N}$ application rate and planting time on plant growth, yield, and nutritional quality attributes of $B$. alba under the influence of Canadian maritime climatic conditions.

\section{Materials and Methods}

The study was carried out between 2018 and 2019 in the greenhouse and laboratory in the Department of Plant, Food, and Environmental Sciences; and the fieldwork was done in the Faculty of Agriculture Demonstration Garden, Truro, NS. The location is at latitude $45^{\circ} 37^{\prime} 56.11^{\prime \prime} \mathrm{N}$, longitude $63^{\circ} 26^{\prime} 21.31^{\prime \prime} \mathrm{S}$, and altitude $32 \mathrm{~m}$.
2.1. Greenhouse Seedling Propagation. Seedlings were raised in the greenhouse located in the Department of Plant, Food and Environmental Sciences, Dalhousie Agricultural Campus, Truro, NS. Seeds of B. alba were obtained from Richters Herbs, Goodwood, ON, Canada. General-purpose Pro-mix BX potting medium (perlite: 10-14\%, vermiculite: $3-7 \%$, sphagnum peat moss: $79-87 \%$ ) and urea (CO(NH2)2) $46 \%$ for $\mathrm{N}$ source were purchased from a local retailer in Truro, NS. The B. alba seeds were primed in water for $24 \mathrm{~h}$ and sown in seed trays filled with Pro-mix BX potting medium. The greenhouse photoperiod and temperature were set at a $12 \mathrm{~h}$ light cycle, $118 * 10 \mathrm{FC}$ luminous intensity, and $25^{\circ} \mathrm{C}$ in the day and $17^{\circ} \mathrm{C}$ at night. The seedlings were grown for 30 days before transplanting.

2.2. Field Soil Analysis and Weather Condition. Prior to transplanting of seedlings, a composite soil sample $(n=9)$ from the field was collected at a depth of $0-15 \mathrm{~cm}$ and sent to the Nova Scotia Department of Agriculture Laboratory Services, Truro, NS, for chemical element analysis. The concentration of plant-available nutrients in the soil was determined by an inductively coupled plasma optical emission spectrometer (ICP-OES-725, Agilent, California, USA). Additionally, soil samples were analyzed for inorganic- $\mathrm{N}$ ammonium $\left(\mathrm{NH}_{4}{ }^{+}\right)$and nitrate $\left(\mathrm{NO}_{3}{ }^{-}\right)$using Technicon Auto-Analyzer (Technicon Industrial Systems Corp., Tarrytown, NY, USA) after extracting in $2 \mathrm{M}$ potassium chloride solution. The soil data is presented in Table 1 . The mean day and night temperatures, the number of rainfall days, total rainfall, and mean day length were retrieved from the Government of Canada website. The weather data was arranged in a two-week interval throughout the planting duration (June 15 to September 18) (Table 2).

2.3. Field Experiment and Management. The field experiment was conducted in the summer of 2018 at Dalhousie Agricultural Campus Demonstration garden. The soil at the experimental site is a Pugwash sandy loam [22]. In the spring of 2018, the field was plowed and disked prior and beds were raised to about $15 \mathrm{~cm}, 1 \mathrm{~m}$ width, and $9 \mathrm{~m}$ length which were made for the transplanting of seedlings.

2.4. Experimental Design. The field experiment was arranged in a split-plot design $(3 \times 4)$ with three blocks (replications). The experimental factors were three planting times of early season planting (15 June-3 August), mid-season planting (6 July-20 August), and late season planting (4 August-18 September); and four $\mathrm{N}$ fertilizer application rates, namely, control $\left(0 \mathrm{~kg} \mathrm{~N} \mathrm{ha}^{-1}\right)$, low $\left(40 \mathrm{~kg} \mathrm{~N} \mathrm{ha}^{-1}\right)$, medium $(80 \mathrm{~kg} \mathrm{~N}$ $\left.\mathrm{ha}^{-1}\right)$, and high $\left(120 \mathrm{~kg} \mathrm{~N} \mathrm{ha}^{-1}\right)$. The $\mathrm{N}$ source was urea. Each block was partitioned into three whole plots and randomly assigned to the three planting times. Each whole plot was then partitioned into four subplots, and the $\mathrm{N}$ rates were assigned randomly. The hardened $B$. alba seedlings were 
TABLE 1: Soil chemical elements, organic matter, and $\mathrm{pH}$ of the experimental site at $0-15 \mathrm{~cm}$ before planting.

\begin{tabular}{lccc}
\hline Chemical elements & $\mathrm{kg} \mathrm{ha}^{-1}$ & Chemical elements & $\mathrm{mg} \mathrm{kg}^{-1}$ \\
\hline Phosphorus (P) & 573 & Boron (B) & $<0.50$ \\
Potassium (K) & 396 & Copper (Cu) & 1.40 \\
Calcium (Ca) & 2532 & Iron (Fe) & 124.0 \\
Magnesium (Mg) & 267 & Manganese (Mn) & 60.0 \\
Sodium (Na) & 22 & Zinc (Zn) & 2.21 \\
Sulphur (S) & 26 & Organic matter & $3.5 \%$ \\
Aluminum (Al) & 1579 & pH & 6.38 \\
\hline
\end{tabular}

TABLE 2: Mean air temperature, day length, number of rainfall days, and rainfall amount throughout the planting season in summer 2018 [21].

\begin{tabular}{|c|c|c|c|c|c|c|}
\hline \multirow[b]{2}{*}{ Planting date } & \multirow[b]{2}{*}{ Maximum } & \multicolumn{2}{|c|}{ Air temperatures $\left({ }^{\circ} \mathrm{C}\right)$} & \multicolumn{2}{|c|}{ Mean day } & \multirow{2}{*}{$\begin{array}{c}\text { Total } \\
\text { Rainfall }(\mathrm{mm})\end{array}$} \\
\hline & & Minimum & Mean & Length (hr day ${ }^{-1}$ ) & Rainfall days & \\
\hline Jun $15-$ Jun 30 & 28.4 & 4.6 & 14.6 & 15.32 & 5 & 122.2 \\
\hline Jul 1-Jul 15 & 32.9 & 7.6 & 19 & 15.22 & 2 & 15.8 \\
\hline Jul 16-Jul 31 & 30.5 & 11.7 & 21.8 & 15.14 & 5 & 31.6 \\
\hline Aug 1-Aug 15 & 32.7 & 9 & 21.8 & 14.21 & 5 & 31.1 \\
\hline Aug 16-Aug 31 & 29.2 & 7.7 & 18.4 & 13.41 & 5 & 33.7 \\
\hline Sept $1-$ Sept 18 & 27.7 & 1.6 & 16 & 12.59 & 3 & 46.1 \\
\hline
\end{tabular}

transplanted at a spacing of $30 \mathrm{~cm} \times 30 \mathrm{~m}$. Sixteen seedlings were accommodated in an experimental unit of a $1 \mathrm{~m}^{2}$ area. Urea was supplemented to the plants after 15 days of field transplanting in a single basal dose. The plots of $1 \mathrm{~m}^{2}$ each were separated by $1 \mathrm{~m}^{2}$ of bare soil strips (check) to prevent lateral flow and run-on of water treatments. Black polythene mulch was used to cover bare soil strips to suppress weed growth. Plants were watered regularly based on soil moisture conditions.

2.5. Plant Measurement and Data Collection. Plant height was measured from four plants selected from the middle of each experimental plot to eliminate edge effects. The lengths of 20 randomly selected leaves were measured from four plants and were averaged to a single value using a meter rule. Stem thickness was measured using a digital Vernier caliper. Leaf chlorophyll content was measured with soil plant analysis development (SPAD) 502 chlorophyll meter (Spectrum Technologies Inc., Illinois, USA). Plant growth components were determined at 45, 60, and 75 days after sowing (DAS) while yield data such as the number of branches, total plant yield, and leaf dry matter content (LDMC) were obtained after 75 DAS. The leaf dry matter content was determined according to procedures by [23].

2.6. Harvesting, Processing, and Storage. The harvested B. alba resh leaves and tender stems at 75 DAS from each plot were cleaned with deionized water and cut into small pieces of approximately 2 to $3 \mathrm{~cm}$ in length. Bulked samples were flash-frozen using liquid $\mathrm{N}$ for 60 seconds, transferred immediately into sealed plastic bags, and stored at $-20^{\circ} \mathrm{C}$. One hundred (100) to $150 \mathrm{~g}$ portions of the plant samples were freeze-dried using Dura-Stop MP Freeze Dryer Tray Dryer (TD5C0C18A0, FTS Systems, Stone Ridge, NY, USA) at $-40^{\circ} \mathrm{C}$ for $36 \mathrm{~h}$ followed by $10^{\circ} \mathrm{C}$ for $12 \mathrm{~h}$. The freeze-dried samples were powdered using a coffee grinder and stored at $-20^{\circ} \mathrm{C}$ in sterilized containers for tissue analysis.

2.7. Total Phenolic Assay. Total phenolic content was measured according to the Folin-Ciocalteu method [24] and modified by [25]. Absorption was measured at $760 \mathrm{~nm}$ using a UV-vis spectrophotometer (Tecan Infinite ${ }^{\circledR}$ M200 PRO, Morrisville, North Carolina, USA). Results were expressed as $\mathrm{mg}$ of gallic acid equivalent (GAE) $\mathrm{g}^{-1}$ dry weight.

2.8. Total Carotenoids Assay. Total carotenoid content was measured according to a method modified from [26]. Absorbance was measured by a UV-vis spectrophotometer at $470 \mathrm{~nm}$. Total carotenoids were calculated according to the method by [27], and the results were expressed in $\mu \mathrm{g} \mathrm{g}^{-1}$ dry weight. The total carotenoid content was calculated according to a formula based on [27] given below, and results were expressed in $\mathrm{mgg}^{-1} \mathrm{DW}$.

$$
C=\frac{\operatorname{Abs} \times 10^{4} \times V}{A_{1 \mathrm{~cm}}^{1 \%} \times W},
$$

where Abs is the absorbance measured at $470 \mathrm{~nm}, 10^{4}$ is the conversion factor to obtain the concentration in units of $\mu \mathrm{g}$ $\mathrm{g}^{-1}, V$ is the volume of extract $(\mathrm{mL}), W$ is the sample weight (g), and $A_{1 \mathrm{~cm}}^{1 \%}$ is the absorption coefficient. Lutein is the major carotenoid in $B$. alba [28]. Therefore, an absorption coefficient of 2550 was used, and $\mathrm{W}$ is the sample weight in grams (g).

2.9. Nitrate Assay. Nitrate in plant tissue samples was measured by nitration of salicylic acid [29, 30]. Total nitrate concentrations were calculated and expressed in $\mathrm{mg} \mathrm{kg}^{-1}$ dry weight. 
2.10. Statistical Analysis. Data was analyzed using the MIXED procedure of Statistics analysis software (SAS Institute Inc.) for analysis of variance (ANOVA) to test onetime and repeated measurements. Total N, ammoniumnitrogen $\left(\mathrm{NH}_{4}{ }^{+-} \mathrm{N}\right)$, and nitrate-nitrogen $\left(\mathrm{NO} 3-{ }^{-} \mathrm{N}\right)$ results from the initial soil test before $\mathrm{N}$ fertilizer application were used as covariates. Multiple means comparison was carried out only when significant ( $p \leq 0.05$ ) or marginally significant ( $p=0.05-0.1)$ effects were obtained using the least square means statement of Proc MIXED with a probability value for difference (pdiff) option to produce $p$ values for all pairwise differences [31, 32]. Letter groupings were generated using a $p=0.05$ level of significance.

\section{Results}

3.1. Soil Chemical Properties and Weather Conditions. The previous plant on the experimental site was ryegrass (Lolium multiflorum). The initial soil nutrient contents except for $N$ were adequate for leafy vegetable production (Table 1).

Soil ammonium-N was $0.589 \mathrm{mg} / \mathrm{L}$ extract, and nitrate$N$ was $1.361 \mathrm{mg} / \mathrm{L}$ extract (data not presented), which were low for green leafy vegetable production. The mean air temperature throughout the planting duration ranged from a maximum of $30^{\circ} \mathrm{C}$ (daytime) to a minimum of $7^{\circ} \mathrm{C}$ (nighttime). The day and night-time air temperatures were the lowest (i.e., $28.4^{\circ} \mathrm{C}$ and $4.6^{\circ} \mathrm{C}$, respectively) in the late planting time and the highest (i.e., about $33^{\circ} \mathrm{C}$ and $10^{\circ} \mathrm{C}$, respectively) in the mid-planting time. The mean air temperature paradigm showed that it was low $\left(15^{\circ} \mathrm{C}\right)$ in the early planting, increased to maximum $\left(22^{\circ} \mathrm{C}\right)$ in mid-planting, and declined $\left(16^{\circ} \mathrm{C}\right)$ in the late planting (Table 2 ).

As expected, the mean day length was higher $(15.32 \mathrm{~h}$ $\mathrm{d}^{-1}$ ) in the early planting (June) and declined toward the end of the planting time in September to the lowest $\left(12.59 \mathrm{~h} \mathrm{~d}^{-1}\right)$ in the late planting time. The highest number of biweekly rainfalls of $5 \mathrm{~mm}$ and highest total rainfall of $122.2 \mathrm{~mm}$ were recorded during the early planting (late June) while the lowest number of biweekly rainfalls of $2 \mathrm{~mm}$ and total rainfall of $15 \mathrm{~mm}$ were recorded in early planting (late July) time, respectively [33] (Table 2).

3.2. Plant Growth and Physiological Parameters. Plant height, leaf length, stem diameter, and chlorophyll content were significantly affected by days after sowing (DAS) $(p<0.001)$ and the interaction between planting time and DAS $(p<0.001)$ but not planting time alone (Table 3$)$.

$N$ rate significantly affected physiological parameters such as chlorophyll content $(p=0.001)$ while planting time and DAS interaction significantly influenced only plant height $(p<0.05)$ and leaf length $(p<0.05)$. Only the significant main effects, that is, interaction of planting time and $\mathrm{N}$ rate, planting time and DAS, and planting time and DAS and $\mathrm{N}$ rate in bold, were subjected to multiple mean comparisons (Table 3).
Plant height, stem diameter, leaf length, and the number of branches increased with time, i.e., from 45 to 75 DAS. Changes in plant height and stem diameter were similar for the early and mid-season plantings from 45 to 75 DAS. During the final harvest, mean plant height and stem diameter ranged from 26.3 to $32.9 \mathrm{~cm}$ and 14.36 to $18.53 \mathrm{~cm}$, respectively. The highest plant height and diameter were recorded during the mid-season planting, but it was not significantly different from late planting. Early planting led to $25 \%$ and $29 \%$ reductions in plant height and stem diameter, respectively, compared to the late planting. Leaf length during the early and mid-plantings was not significantly different but that of the late planting showed a $33 \%$ decline in leaf length (Figures 1(a)-1(c)).

The interaction between $\mathrm{N}$ rate and planting time significantly increased plant height, leaf length, and the number of branches in the early season planting. Plant height in the early planting ranged from 12.7 to $14.8 \mathrm{~cm}$ while the leaf length ranged from 8.3 to $9.8 \mathrm{~cm}$, and the number of branches ranged from 6 to 10. These growth parameters were the highest in the low $\mathrm{N}$ applied plants but the least in the control plants (Figure 2). The corresponding increase in plant height, leaf length, and branches amounted to $16.5 \%$, $18.1 \%$, and $66.6 \%$, respectively (Figure 2 ).

\subsection{LeafChlorophyll Content. The late planting had a strong} negative effect on chlorophyll content as continuous leaf greenness slightly decreased in the late planting at 75 DAS, which was $14.3 \%$ higher than the control plants. Leaf chlorophyll content reached 47.1 SPAD value for the late planting and 36.9 SPAD value for both the early and midseason planting time (Figure 3(a)). Leaf chlorophyll content was also significantly improved with the interaction effect of $\mathrm{N}$ rate and DAS in comparison to control plants without being affected by the different $\mathrm{N}$ application rates (Figure 3(b)).

3.4. Nutritional Quality Parameters. The interaction effect of planting time and $\mathrm{N}$ rates significantly $(p<0.05)$ influenced LDMC, TPC, and TCC but total yield $(p=0.08)$ and nitrate contents $(p=0.022)$ were not affected. Total yield, LDMC, TPC, TCC, and nitrate contents were not affected by planting time, total soil $\mathrm{N}$, and ammonium-N while TPC and TCC measured per dry weight were significantly affected by $\mathrm{N}$ rate across all the different planting times with marginal effect on soil nitrate $(p=0.06)$ (Table 4$)$.

3.5. Leaf Dry Matter Content and Total Plant Yield. Effects of planting time and $\mathrm{N}$ rate on LDMC did not follow any clear trend. However, LDMC was consistently high in late planting irrespective of $N$ rate (Table 5). Effects of planting time and $\mathrm{N}$ rate on total yield were high at $89 \%$ more than those of the control treatment in the early planting with low $\mathrm{N}$ rate, being low at $17 \%$ and $11 \%$ than control only in the mid- and late planting with medium $\mathrm{N}$ rate, respectively (Table 5). Overall, the yield was increased at 
TABLE 3: Analysis of variance $p$ values for the main and interaction effects of planting time (PT), nitrogen (N) rate, days after sowing (DAS), and total soil $\mathrm{N}$, nitrate- $\mathrm{N}$, and ammonium- $\mathrm{N}$ covariates on plant height, leaf length, stem diameter, and chlorophyll content.

\begin{tabular}{|c|c|c|c|c|c|}
\hline Source of variation & Plant height & Leaf length & Stem diameter & Number of branches & Chlorophyll content \\
\hline PT & 0.15 & 0.22 & 0.09 & 0.32 & 0.27 \\
\hline $\mathrm{N}$ rate & 0.54 & 0.32 & 0.10 & 0.63 & 0.001 \\
\hline $\mathrm{PT} \times N$ rate & $0.04^{*}$ & 0.03 & 0.28 & $0.03^{*}$ & 0.46 \\
\hline DAS & $<0.001$ & $<0.001$ & $<0.001$ & - & $<0.001$ \\
\hline $\mathrm{PT} \times \mathrm{DAS}$ & $<0.001$ & $<0.001$ & $<0.001$ & - & $<0.001$ \\
\hline $\mathrm{N}$ rate $\times \mathrm{DAS}$ & 0.44 & 0.62 & 0.60 & - & 0.05 \\
\hline $\mathrm{PT} \times N$ rate $\times$ DAS & 0.18 & 0.33 & 0.71 & - & 0.39 \\
\hline Total soil N & 0.31 & 0.97 & 0.74 & 0.63 & 0.81 \\
\hline Soil nitrate-N & 0.19 & 0.99 & 0.87 & 0.11 & 0.63 \\
\hline Soil ammonium-N & 0.89 & 0.69 & 0.20 & 0.78 & 0.73 \\
\hline
\end{tabular}

${ }^{*} P$ values $(p<0.05)$ of significant effects that require multiple means comparison are shown in bold; ${ }^{* *} P$ values $(p<0.05 / 0.05-0.1)$ of significant and marginally significant covariates are underlined.

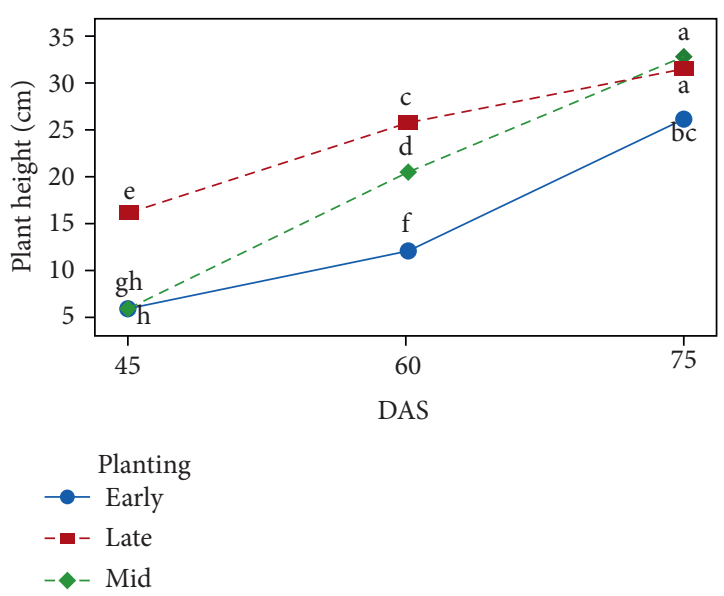

(a)

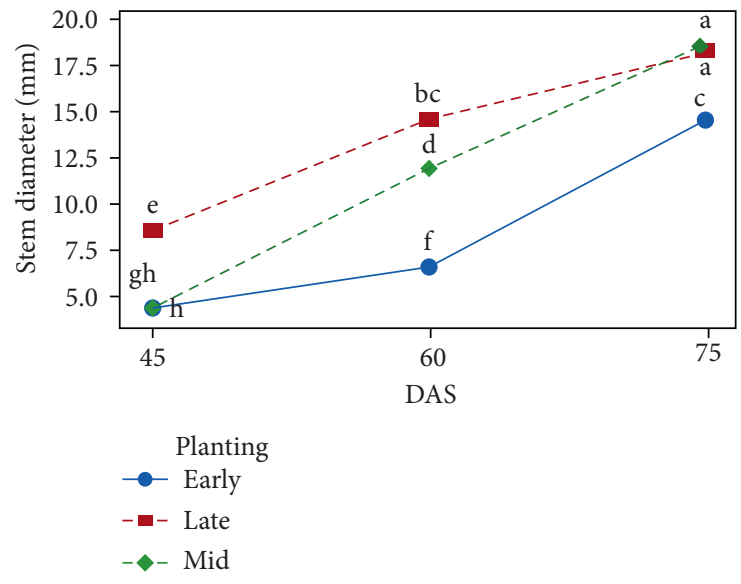

(b)

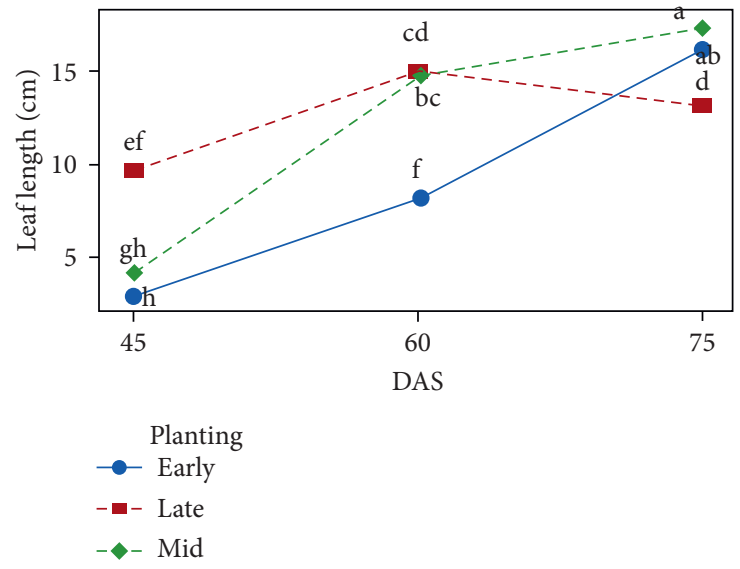

(c)

Figure 1: Interaction effects of planting time and days after sowing (DAS) on (a) plant height (cm), (b) leaf length (cm), and (c) stem diameter $(\mathrm{mm})$. Means sharing the same letter are not significantly different at $p<0.05$.

the mid-season planting irrespective of the $\mathrm{N}$ rate with the highest yield recorded by the medium $\mathrm{N}$ rate which was $169 \%$ higher than the control.
3.6. TPC, TCC, Moisture Content, and Nitrate Content. Overall, the average TPC declined from early planting (7.25 mg GAE g-1 DW) to mid-planting time (6.50 mg GAE 


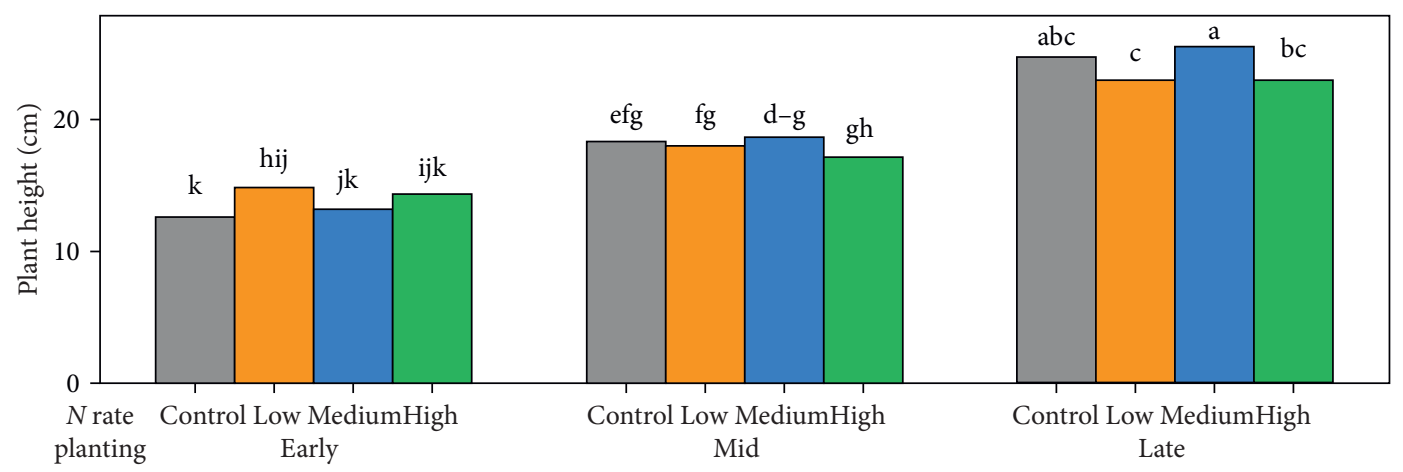

(a)

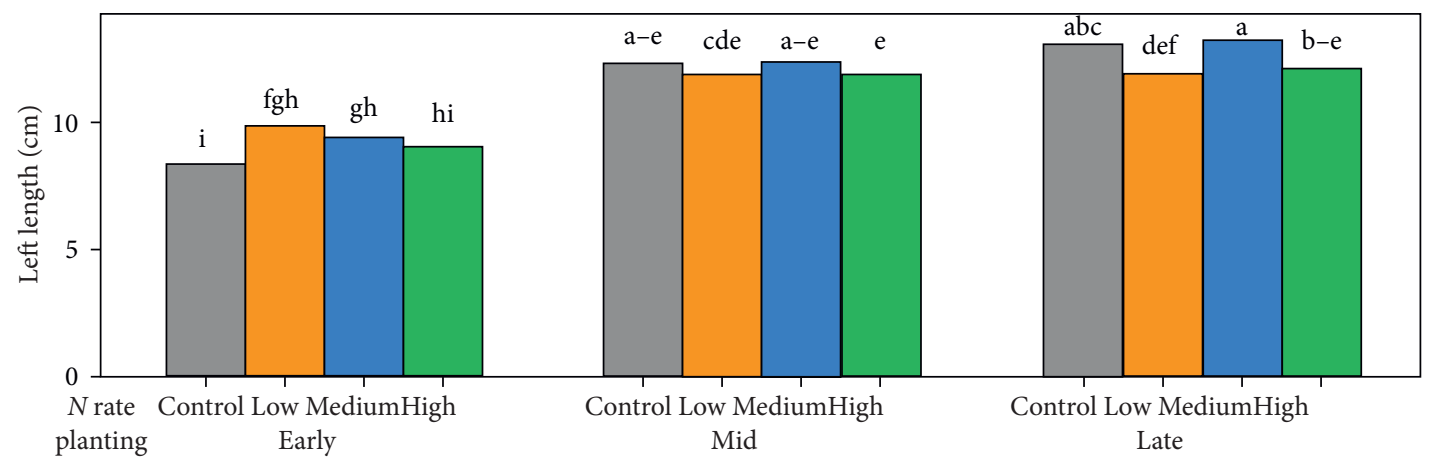

(b)

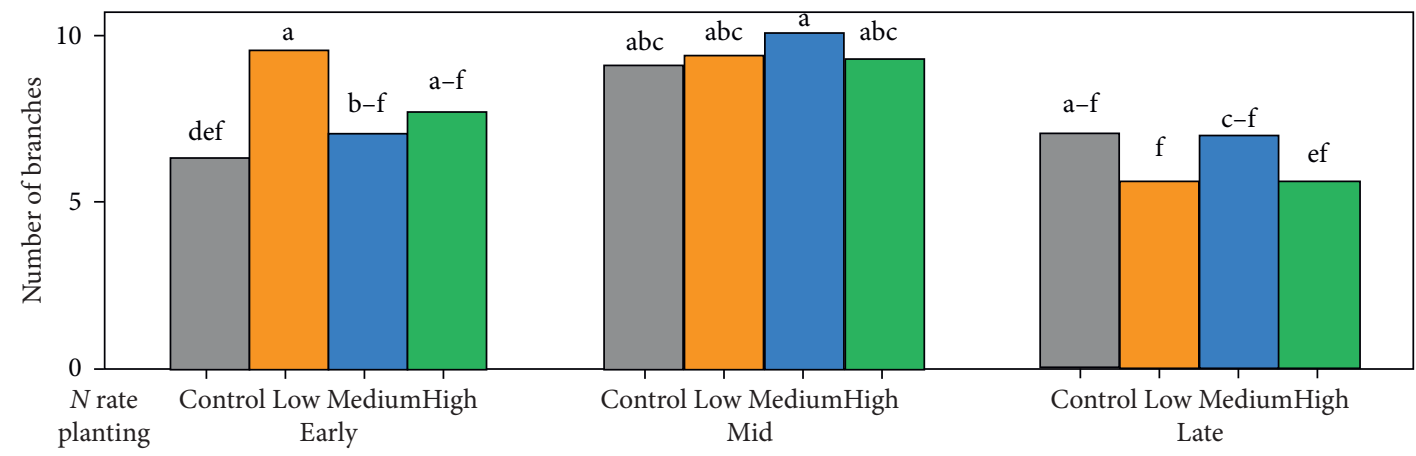

(c)

Figure 2: Interaction effects of planting time and $\mathrm{N}$ rate on plant height $(\mathrm{cm})$, leaf length $(\mathrm{cm})$, and stem diameter $(\mathrm{mm})$. Means sharing the same letter are not significantly different at $p<0.05$.

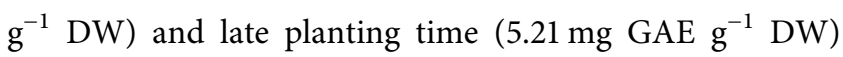
(Table 6).

The decrease corresponded to $11 \%$ from early planting to mid-planting time, followed by a decline by $24 \%$ from midplanting to late planting time. TPC was significantly higher in the control $\mathrm{N}\left(7.65 \mathrm{mg} \mathrm{GAE} \mathrm{g}^{-1} \mathrm{DW}\right)$ and the lowest in

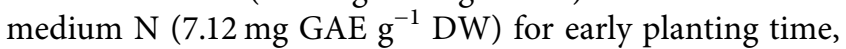
but higher in medium $\mathrm{N}$ for mid-planting time $(7.07 \mathrm{mg}$ GAE $\left.\mathrm{g}^{-1} \mathrm{DW}\right)$ and the lowest in high $\mathrm{N}$ (5.90 $\mathrm{mg} \mathrm{GAE} \mathrm{g}^{-1}$ DW). TPC was higher in control for late planting time (5.51 $\left.\mathrm{mg} \mathrm{GAE} \mathrm{g}^{-1} \mathrm{DW}\right)$ and the lowest in high $\mathrm{N}(4.88 \mathrm{mg}$ GAE $\left.\mathrm{g}^{-1} \mathrm{DW}\right)$. TCC increased from early planting $(1291 \mu \mathrm{g}$ g-1 DW) to mid-planting time $(1606 \mu \mathrm{g}$ g-1 DW) but decreased in late planting time $\left(1552 \mu \mathrm{g} \mathrm{g}^{-1} \mathrm{DW}\right)$. The increase in TCC was $24 \%$ from early planting to mid-planting time, after which it decreased by $3 \%$ from mid-planting to late planting time. The effect of $\mathrm{N}$ rate on TCC was higher with low $\mathrm{N}\left(1446 \mu \mathrm{g}^{-1} \mathrm{DW}\right)$ and the least in the control $\left(1134 \mu \mathrm{g}^{-1} \mathrm{DW}\right)$ for early planting time, whereas midplanting had the highest TCC in medium N $\left(1804 \mu \mathrm{g}^{-1} \mathrm{DW}\right)$ and the lowest in low $\mathrm{N}\left(1529 \mathrm{ug}^{-1} \mathrm{DW}\right)$. However, for late planting time, TCC was the highest in plants applied with high $\mathrm{N}\left(1767 \mu \mathrm{g}^{-1} \mathrm{DW}\right)$ compared to the rest (Table 6). Overall, the moisture content was greater than $90 \%$ with an average of $94 \%$ for control and low $\mathrm{N}$, and $95 \%$ for medium and high $\mathrm{N}$, respectively (Table 7 ). The high and medium $\mathrm{N}$ rates resulted in the highest nitrate content of the plants (254 $\left.\mathrm{mg} \mathrm{kg}^{-1} \mathrm{DW}\right)$ compared to the low rate and control (Table 7). There was no difference in nitrate of plants treated with a low $\mathrm{N}$ rate versus control. 


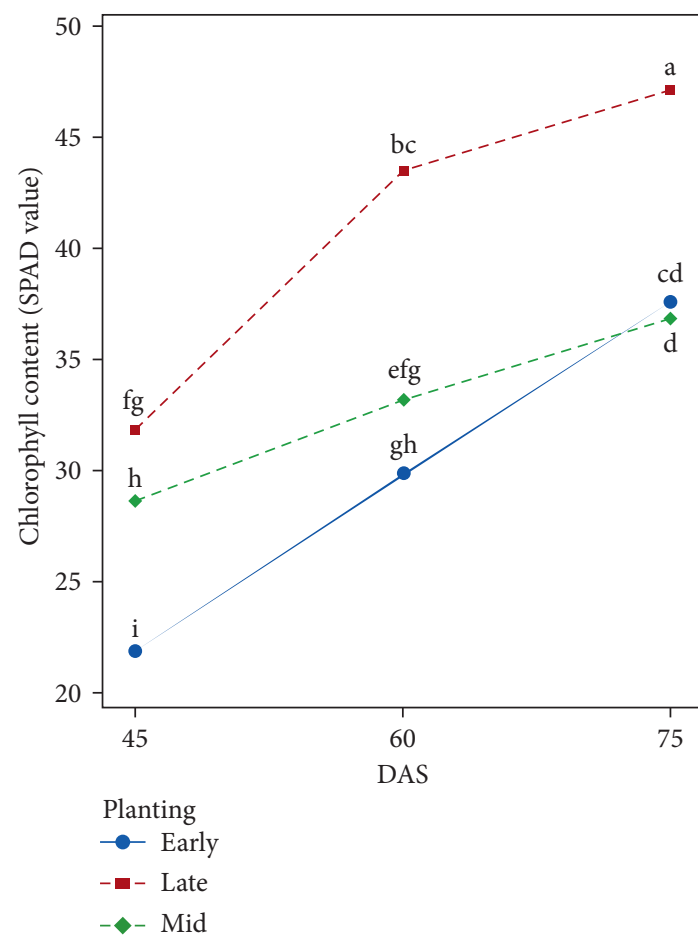

(a)

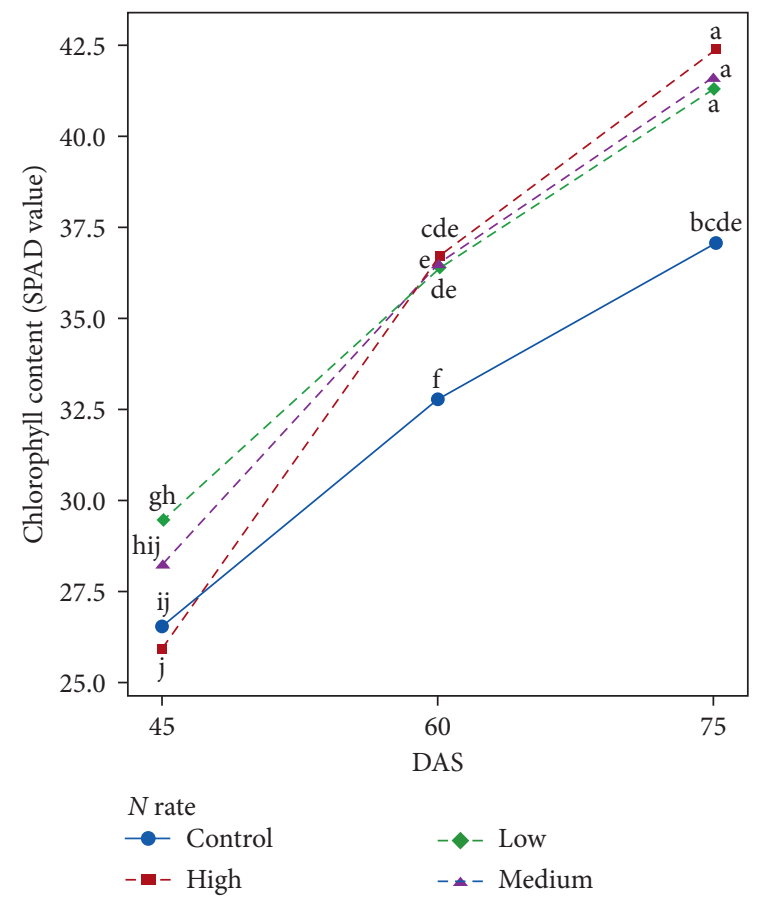

(b)

FIGURE 3: Interaction effects of (a) planting time and days after sowing (DAS) and (b) nitrogen (N) rate and DAS on leaf chlorophyll content. Means sharing the same letter are not significantly different at $p<0.05$.

\section{Discussion}

The soil of the experimental site had more $\mathrm{P}$ and $\mathrm{K}$ (i.e., $573 \mathrm{~kg} \mathrm{P} 2 \mathrm{O} 5 \mathrm{ha}^{-1}$ and $396 \mathrm{~kg} \mathrm{~K} 2 \mathrm{O} \mathrm{ha}^{-1}$ ) than the recommended fertilizer dose of $60 \mathrm{P} \mathrm{kg} \mathrm{ha}^{-1}$ and $40 \mathrm{~K} \mathrm{~kg} \mathrm{ha}^{-1}$ for B. alba [34]. Other soil macro- and micronutrients such as calcium (Ca), magnesium ( $\mathrm{Mg})$, boron (B), zinc ( $\mathrm{Zn})$, and soil properties such as $\mathrm{pH}$ and organic matter were adequate to produce B. alba [34]. Transplanted seedlings at mid- and late season plantings were exposed to high soil and air temperatures during the warmest summer month of July (Table 2), which enhanced $B$. alba plant establishment and growth. During mid-planting between July 16 and August 15 , there was stable air temperature, extended day length, and frequent but low rainfall intensity which favored $\mathrm{N}$ uptake and increased plant growth. Ribeiro et al. [15, 35] demonstrated that vegetative growth and leaf elongation of amaranth (Amaranthus tricolor L.), also a tropical leafy vegetable plant, were greatly reduced under decreasing day length and mean daily air temperatures [19, 35]. In the present study, $B$. alba leaf length was reduced due to late planting (Figure 1(b)), which agrees with the finding by $[15,35]$.

Low $\mathrm{N}$ rate was found to be optimum for maximum growth of $B$. alba during the early planting season. This agrees with [36] who reported that $\mathrm{N}$ application promoted leaf and stem production but increased vegetative growth but plateaued at an optimum $N$ rate $[9,37]$. This is because the absorption and translocation of mineral nutrients by plants from the soil are influenced by soil and air
TABLE 4: Analysis of variance $p$ values for the main and interaction effects of planting time $(\mathrm{PT})$, nitrogen $(\mathrm{N})$ rate and total soil $\mathrm{N}$, nitrate- $\mathrm{N}$, and ammonium- $\mathrm{N}$ covariates on the number of branches, total yield, and leaf dry matter content (LDMC), total phenolic content (TPC), and total carotenoid content (TCC).

\begin{tabular}{lccccc}
\hline $\begin{array}{l}\text { Source of } \\
\text { variation }\end{array}$ & $\begin{array}{l}\text { Total } \\
\text { yield }\end{array}$ & LDMC & TPC & TCC & $\begin{array}{c}\text { Nitrate } \\
\text { content }\end{array}$ \\
\hline PT & 0.13 & 0.38 & 0.20 & 0.38 & 0.63 \\
N rate & 0.15 & 0.63 & 0.04 & 0.03 & $\mathbf{0 . 0 6}$ \\
PT $\times$ N rate & $\mathbf{0 . 0 8}$ & $\mathbf{0 . 0 1}$ & $\mathbf{0 . 0 4}$ & $\mathbf{0 . 0 2}$ & 0.22 \\
Total soil N & 0.96 & 0.28 & 0.87 & 0.88 & 0.57 \\
Soil nitrate-N & 0.86 & 0.44 & 0.55 & 0.33 & 0.72 \\
Soil ammonium- & 0.20 & 0.92 & 0.70 & 0.55 & 0.66 \\
N & & & & & \\
\hline
\end{tabular}

${ }^{*} P$ values $(p<0.05 / 0.05-0.1)$ of significant and marginally significant effects that require multiple means comparison are shown in bold.

temperatures. A study of absorption of ammonium $\left(\mathrm{NH}_{4}^{+}\right)$ and nitrate $\left(\mathrm{NO}_{3}{ }^{-}\right)$by lettuce (Lactuca sativa) plants indicated increased uptake of ions from the growing medium when air and root temperatures increased from $8^{\circ} \mathrm{C}$ to $23^{\circ} \mathrm{C}$ [38]. It was further explained that $\mathrm{NO}_{3}{ }^{-}$uptake rate was more affected by temperature than $\mathrm{NH}_{4}^{+}$absorption. Therefore, the cooler air and soil temperatures in the months of June and early July (Table 2) seemed to have reduced plant growth in the early season planting compared to the midand late season plantings. Furthermore, appreciable growth of the control plants in $\mathrm{N}$ limiting conditions of the mid-and late season plantings can be ascribed to increased efficiency of $B$. alba at warm temperatures and high light intensities in 
TABLe 5: Interaction effect of planting time (PT) and nitrogen (N) rate on leaf dry matter content (LDMC) and total yield.

\begin{tabular}{|c|c|c|c|}
\hline PT & $\mathrm{N}$ rate & $\operatorname{LDMC}\left(\mathrm{mg} \mathrm{g}^{-1}\right)$ & Total yield (g plant $\left.{ }^{1}\right)$ \\
\hline Early & Control & $52.9 \mathrm{c}-\mathrm{i}$ & $111.3 \mathrm{~g}$ \\
\hline Early & Low & $46.1 \mathrm{~g}-\mathrm{j}$ & $210.4 \mathrm{def}$ \\
\hline Early & Medium & $49.4 \mathrm{~d}-\mathrm{j}$ & 185.2 ef \\
\hline Early & High & $48.1 \mathrm{f}-\mathrm{j}$ & $181.6 \mathrm{f}$ \\
\hline Mid & Control & $38.3 \mathrm{j}$ & $472.3 \mathrm{ab}$ \\
\hline Mid & Low & $49.0 \mathrm{e}-\mathrm{i}$ & $436.3 \mathrm{abc}$ \\
\hline Mid & Medium & 45.7 hi & $512.1 \mathrm{a}$ \\
\hline Mid & High & $43.2 \mathrm{ij}$ & $435.9 \mathrm{abc}$ \\
\hline Late & Control & $63.1 \mathrm{a}$ & 341.7 a-d \\
\hline Late & Low & $60.3 \mathrm{a}-\mathrm{g}$ & $277.4 \mathrm{c}-\mathrm{f}$ \\
\hline Late & Medium & $56.2 \mathrm{~b}-\mathrm{i}$ & $381.8 \mathrm{ab}$ \\
\hline Late & High & $58.2 \mathrm{a}-\mathrm{h}$ & $311.2 \mathrm{~b}-\mathrm{f}$ \\
\hline
\end{tabular}

Means sharing the same alphabetical letters within the same column are not significantly different at the $5 \%$ level; c-i represents cdefghi.

TABLE 6: Interaction effect of planting time (PT) and nitrogen (N) rate on total phenolic content (TPC) and total carotenoid content (TCC).

\begin{tabular}{lcccc}
\hline PT & $\begin{array}{c}\text { N rate } \\
\left(\mathrm{kg} \mathrm{ha}^{1}\right)\end{array}$ & $\begin{array}{c}\text { TPC } \\
\left(\mathrm{mg} \mathrm{GAE} \mathrm{g}^{-1} \mathrm{DW}\right)\end{array}$ & $\begin{array}{c}\text { TCC } \\
\left(\mu \mathrm{g} \mathrm{g}^{-1} \mathrm{DW}\right)\end{array}$ & $\begin{array}{c}\text { Moisture } \\
(\%)\end{array}$ \\
\hline Early & Control & $7.65 \mathrm{a}$ & $1134 \mathrm{j}$ & 94.8 \\
Early & Low & $7.19 \mathrm{ab}$ & $1446 \mathrm{f}-\mathrm{i}$ & 95.4 \\
Early & Medium & $7.12 \mathrm{abc}$ & $1300 \mathrm{hij}$ & 95.1 \\
Early & High & $7.52 \mathrm{ab}$ & $1284 \mathrm{ij}$ & 95.2 \\
Mid & Control & $6.73 \mathrm{bc}$ & $1543 \mathrm{zd}-\mathrm{i}$ & 96.2 \\
Mid & Low & $6.33 \mathrm{c}-\mathrm{f}$ & $1529 \mathrm{ze}-\mathrm{i}$ & 95.2 \\
Mid & Medium & $7.07 \mathrm{ab}$ & $1804 \mathrm{abz}$ & 95.5 \\
Mid & High & $5.90 \mathrm{~d}-\mathrm{g}$ & $1547 \mathrm{z} \mathrm{c-i}$ & $1427 \mathrm{~g}-\mathrm{j}$ \\
Late & Control & $5.51 \mathrm{efg}$ & $1459 \mathrm{z} \mathrm{f}-\mathrm{j}$ & 95.7 \\
Late & Low & $5.41 \mathrm{fgh}$ & $1556 \mathrm{z} \mathrm{b}-\mathrm{j}$ & $1767 \mathrm{a} \mathrm{c-f}$ \\
Late & Medium & $5.05 \mathrm{gh}$ & 93.6 \\
Late & High & $4.88 \mathrm{~h}$ & 94.3 \\
\hline
\end{tabular}

Means sharing the same alphabetical letters within the same column are not significantly different at the $5 \%$ level; $\mathrm{c}$ - $\mathrm{f}$ represents cdef.

TABLE 7: Main effect of nitrogen $(\mathrm{N})$ rate on plant moisture content and nitrate concentration.

\begin{tabular}{lcr}
\hline $\mathrm{N}$ rate & Moisture & Nitrate content \\
\hline$\left(\mathrm{kg} \mathrm{ha}^{1}\right)$ & $(\%)$ & $\left(\mathrm{mg} \mathrm{kg}^{-1} \mathrm{DW}\right)$ \\
Control & 94.9 & $187 \mathrm{~b}$ \\
Low & 94.8 & $182 \mathrm{~b}$ \\
Medium & 95.0 & $254 \mathrm{a}$ \\
High & 95.0 & $236 \mathrm{a}$ \\
\hline
\end{tabular}

Means sharing the same alphabetical letters within the same column are not significantly different at the $5 \%$ level.

the months of July-August $[15,35,38]$, which is a characteristic of C4 plants. The slightly steady air temperature, precipitation, and the more frequent but moderate amount of rainfall may have contributed to steady and better absorption of available soil water and nutrients and, consequently, high growth performance in the mid- and late season plantings. The significant increase in plant height and leaf length observed at late planting can also be attributed to the climatic conditions that led to robust and well-established B. alba seedlings.

Leaf chlorophyll content was promoted by an increase in $\mathrm{N}$ fertilizer rate $(p=0.001)$. Chlorophyll synthesis is dependent on mineral nutrition, particularly N. Consequently,
$\mathrm{N}$ fertilization promotes the formation of photosynthetic pigments by enhancing the amount of stromal and thylakoid proteins in plant leaves [39]. On the contrary, chlorophyll pigments tend to diminish when $\mathrm{N}$ is above the optimal level. Furthermore, excessive application of $\mathrm{N}$ reduces leaf lifespan by reducing tensile strength due to low carbon to $\mathrm{N}$ ratio, increasing leaf sensitivity, and susceptibility to pests and disease $[39,40]$. An experiment conducted on five leafy vegetables to study functional components, antioxidant activity, and color parameters under different levels of photoperiod reported a significant increase in the accumulation of chlorophyll pigments under $12 \mathrm{~h}$ photoperiod compared to photoperiod range of 6 to $12 \mathrm{~h}$ or 18 to $24 \mathrm{~h}$ 
[41]. Therefore, it was suggested that reduced day length during late planting might have increased leaf chlorophyll content.

The total yield of $B$. alba in the present study agreed with what was reported by $[16,42]$. The increased plant growth of low $\mathrm{N}$ fertilized plants was translated into a significantly high yield in early planting. There was no significant difference between the plant yield of the control and the $\mathrm{N}$ applied plants in mid-and late plantings, which can be attributed to background soil nutrients contents. Sugars and fibers which are the main constituents of dry matter can be altered by $\mathrm{N}$ fertilizer [43]. Nitrogen deprivation in leaves increases sugar and dietary fiber accumulation, which leads to an increase in leaf dry matter content (LDMC) [43] as found in the present study. Leaves with high LDMC are relatively tough and are more resistant to physical hazards [23]. Nitrogen rate not only regulates LDMC but also regulates dry matter allocation between root and shoot $[16,42]$. The increase in plant fresh weight in $B$. alba is significantly and positively associated with branch number, stem size, and leaf length [44], which influence plant yield.

Phenolic concentration was reduced in the late planting and could be due to decreased photoperiod from $15 \mathrm{~h}$ to $12 \mathrm{~h}$ (Table 2). Similar research results were mentioned in a study by [41]. The variations in phenolic compounds from one harvest to another were reported in previous studies conducted on tomato leaves and lettuce, and the variations were attributed to seasonal differences $[45,46]$. In general, increased $\mathrm{N}$ application reduced phenolic composition in plants due to the deactivation of some key enzymes in the phenolic synthesis pathway [45]. The phenolic concentration recorded in the present study under Canadian Atlantic maritime conditions is low compared to the concentrations reported in tropical climatic conditions for the same crop species. For instance, [47] recorded $15.5 \mathrm{mg}$ GAE g-1 DW from the buds of $B$. alba whereas [48] recorded $28.17 \mathrm{mg}$ GAE g-1 DW. As the $\mathrm{N}$ application rate increased, plant metabolism shifts toward the synthesis of $\mathrm{N}$-containing compounds (protein) from carbon-containing sugar compounds [9]. Since biosynthesis of carotenoids is closely related to protein synthesis, $\mathrm{N}$ application can increase carotenoid synthesis [43]. Planting time had no effect on total carotenoid content, but $\mathrm{N}$ rate had little effect $(p=0.06)$. Carotenoid concentration varied from 1135 to $1805 \mu \mathrm{g} \mathrm{g}^{-1} \mathrm{DW}$ across planting times and $\mathrm{N}$ rates (Table 6). The highest carotenoid concentration of $1805 \mu \mathrm{gg}^{-1} \mathrm{DW}$ was recorded from the mid-planting at a medium $\mathrm{N}$ rate, which was $59 \%$ higher than the control. Overall, a considerable increase in carotenoid concentration was noticed under the influence of the $\mathrm{N}$ rate, and this increment was consistent each time of planting. Carotenoid content in our study was in good amount compared to spinach $\left(1.96 \mathrm{mg} \mathrm{g}^{-1}\right.$ DW), amaranth (Amaranthus caudatus) $\left(1.18 \mathrm{mg} \mathrm{g}^{-1} \mathrm{DW}\right)$, and curry leaf (Murraya koenigii) $\left(1.99 \mathrm{mg} \mathrm{g}^{-1} \mathrm{DW}\right)$ in the study conducted by [49].

Leaf tissue moisture contents in all the treatments were greater than $90 \%$. Regardless of $\mathrm{N}$ rate, the amount of nitrate accumulated in B. alba in the present study was remarkably high compared to reports for other vegetables such as lettuce
[50], Beta vulgaris (Beetroot), Apium graveolens (Celery), lettuce, spinach, and Brassica rapa subsp. rapa (Turnips) [50]. These vegetables are known for higher nitrate accumulation greater than $2500 \mathrm{mg} \mathrm{kg}^{-1}$ of fresh weight [50]. Since B. alba is consumed after cooking or boiling (not recommended for eating fresh), it can be expected that leaching of nitrates during cooking will help reduce potential health risks such as blue-baby syndrome also known as infant methemoglobinemia.

\section{Conclusion}

This study showed that $B$. alba, a tropical leafy vegetable, can potentially be grown as a summer leafy vegetable under maritime conditions. It is recommended to transplant the seedlings of $B$. alba previously raised in the greenhouse to the field after the danger of the last frost is passed. From the results of this experiment, it was clear that low atmospheric temperature in the early season can reduce the growth and yield of $B$. alba. Application of a low $\mathrm{N}$ rate can be recommended to achieve a fair amount of plant yield in the early season. However, the maximum plant growth and yield were obtained during the warmest part of the summer months, which coincided with the mid- and late plantings. Increased air temperatures in the mid- and late plantings supported the exorbitant plant growth even under limited $N$ conditions considering the amount of inherent soil nutrients. There was no significant influence of applied $\mathrm{N}$ fertilizer on total phenolics and total carotenoids concentrations in B. alba. It is, therefore, recommended to reduce the rate of $\mathrm{N}$ fertilizer application during hightemperature conditions. Since plant tissue analysis for nitrates showed high nitrate concentration irrespective of $\mathrm{N}$ applied rate, future studies are required to investigate nitrate accumulation in B. alba and potential health risk. Also, future studies are required to investigate phosphorus and potassium fertilizer application.

\section{Data Availability}

The soil analysis, climate, and plant growth and tissue analysis data used to support the findings of this study are included within the article.

\section{Conflicts of Interest}

The authors declare no conflicts of interest with the preparation and submission of this manuscript.

\section{Acknowledgments}

The authors thank Dr. Shivanandh Hongal for providing seed material, Dr. Tessema Astatkie for helping to complete statistical analysis, and Michael Main for his help with the farm activities. Funding for this work was obtained from Nova Scotia Agricultural Department of Agriculture Research Acceleration Project no. RA2016-008. The authors thank the donors of The Vitamin Scholarship for supporting the student for the graduate study. 


\section{References}

[1] N. Gokilamani, N. Muthukumarasamy, M. Thambidurai, A. Ranjitha, and D. Velauthapillai, "Basella alba rubra spinach pigment-sensitized $\mathrm{TiO} 2$ thin film-based solar cells," Applied Nanoscience, vol. 5, no. 3, pp. 297-303, 2015.

[2] S. K. Roy, G. Gangopadhyay, and K. K. Mukherjee, "Is stem twining form of Basella alba L. a naturally occurring variant?" Current Science, vol. 1375, 2010.

[3] S. S. Kumar, P. Manoj, and P. Giridhar, "Nutrition facts and functional attributes of foliage of Basella spp," LWT - Food Science and Technology, vol. 64, no. 1, pp. 468-474, 2015.

[4] N. Lourith and M. Kanlayavattanakul, "Ceylon spinach: a promising crop for skin hydrating products," Industrial Crops and Products, vol. 105, pp. 24-28, 2017.

[5] M. J. Haskell, K. M. Jamil, F. Hassan et al., "Daily consumption of Indian spinach (Basella alba) or sweet potatoes has a positive effect on total-body vitamin A stores in Bangladeshi men," The American Journal of Clinical Nutrition, vol. 80, no. 3, pp. 705-714, 2004.

[6] M. C. Palada and S. M. Crossman, Evaluation of Tropical Leaf Vegetables in the Virgin Islands. Perspectives on New Crops and New Uses, ASHS Press, Alexandria, VA, USA, 1999.

[7] J. Chaput, "Asian vegetables grown in Ontario. Ministry of agriculture, Food and rural affairs," FACTSHEET, vol. 25, 1998, http://www.omafra.gov.on.ca/english/crops/facts/98033.htm.

[8] M. Rajasekar, D. U. Nandhini, V. Swaminathan, and K. Balakrishnan, "A review on role of macro nutrients on production and quality of vegetables," International Journal of Chemical Studies, vol. 5, pp. 304-309, 2017.

[9] F. Albornoz, "Crop responses to nitrogen overfertilization: a review," Scientia Horticulturae, vol. 205, pp. 79-83, 2016.

[10] R. Fernández-Escobar, M. Guerreiro, M. Benlloch, and M. Benlloch-González, "Symptoms of nutrient deficiencies in young olive trees and leaf nutrient concentration at which such symptoms appear," Scientia Horticulturae, vol. 209, pp. 279-285, 2016.

[11] T. A. Adenegan-Alakinde and F. M. Ojo, "Phytochemical and antioxidant properties of forms of Basella," International Journal of Vegetable Science, vol. 25, no. 5, pp. 431-440, 2018.

[12] R. Adhikari, N. Kumar, and S. D. Shruthi, "A review on medicinal importance of Basella alba L," International Journal of Pharmaceutical Sciences and Drug Research, vol. 4, pp. 110-114, 2012.

[13] P. K. Prajapati, S. B. Singh, and S. Jaiswal, "Overview on antiulcer activity of Basella alba: a therapeutic herb," International Journal of Applied Science and Technology, vol. 5, pp. 49-61, 2014.

[14] N. K. Rop, T. M. Mutu, and E. I. C. Kiprop, "Influence of nitrogen fertilizer on the growth, yield, and quality of Indian spinach (Basella alba L.)," African Journal of Horticultural Science, vol. 6, pp. 111-117, 2012.

[15] J. E. Ribeiro, P. J. Pieterse, and S. I. Famba, "Vegetative growth ofAmaranthus hybridusandAmaranthus tricolorunder different watering regimes in different seasons in southern Mozambique," South African Journal of Plant and Soil, vol. 34, no. 3, pp. 201-210, 2017.

[16] F. S. Chapin, A. J. Bloom, C. B. Field, and R. H. Waring, "Plant responses to multiple environmental factors," Bioscience, vol. 37, no. 1, pp. 49-57, 1987.

[17] N. Tremblay and C. Bélec, "Adapting nitrogen fertilization to unpredictable seasonal conditions with the least impact on the environment," HortTechnology, vol. 16, no. 3, pp. 408-412, 2006.

[18] Y.-E. Yoon, S. Kuppusamy, K. M. Cho, P. J. Kim, Y.-B. Kwack, and Y. B. Lee, "Influence of cold stress on contents of soluble sugars, vitamin $\mathrm{C}$ and free amino acids including gammaaminobutyric acid (GABA) in spinach (Spinacia oleracea)," Food Chemistry, vol. 215, pp. 185-192, 2017.

[19] L. A. Weston and M. M. Barth, "Preharvest factors affecting postharvest quality of vegetables," HortScience, vol. 32, pp. 812-881, 1997.

[20] V. Zvalo and A. Respondek, "Spinach vegetable crops production guide for Nova Scotia," 2008, http://nsnewfarmer.ca/ wp-content/uploads/sites/5/2018/02/Spinach-ProductionGuide.pdf.

[21] Government of Canada, "Station results- historical data," 2018, http://climate.weather.gc.ca/historical_data/search_ historic_data_stations_.

[22] Nova Scotia Soil Survey 1948, Soil Survey of Colchester County Nova Scotia, Truro, Nova Scotia, Cambridge, UK, 2020, http:// sis.agr.gc.ca/cansis/publications/surveys/ns/ns19a/index. html.

[23] J. H. C. Cornelissen, S. Lavorel, E. Garnier et al., "handbook of protocols for standardised and easy measurement of plant functional traits worldwide," Australian Journal of Botany, vol. 51, no. 4, pp. 335-380, 2003.

[24] V. L. Singleton and J. A. Rossi, "Colorimetry of total phenolics with phosphomolybdic-phosphotungstic acid reagents," American Journal of Enology and Viticulture, vol. 16, pp. 144-158, 1965.

[25] H. P. V. Rupasinghe, G. M. Huber, C. Embree, and P. L. Forsline, "Red-fleshed apple as a source for functional beverages," Canadian Journal of Plant Science, vol. 90, no. 1, pp. 95-100, 2010.

[26] S. Rivera and R. Canela, "Influence of sample processing on the analysis of carotenoids in maize," Molecules, vol. 17, no. 9, pp. 11255-11268, 2012.

[27] J. Gross, "Carotenoids. pigments in vegetables," in Chlorophylls and Carotenoids, J. Gross, Ed., pp. 79-253, Van Nostrand Reinhold, New York, NY, USA, 1991.

[28] M. Raju, S. Varakumar, R. Lakshminarayana, T. Krishnakantha, and V. Baskaran, "Carotenoid composition and vitamin A activity of medicinally important green leafy vegetables," Food Chemistry, vol. 101, no. 4, pp. 1598-1605, 2007.

[29] D. A. Cataldo, M. Maroon, L. E. Schrader, and V. L. Youngs, "Rapid colorimetric determination of nitrate in plant tissue by nitration of salicylic acid," Communications in Soil Science and Plant Analysis, vol. 6, no. 1, pp. 71-80, 1975.

[30] L. Zhao and Y. Wang, "Nitrate assay for plant tissues," Bioprotocol, vol. 7, no. 2, p. e2029, 2017.

[31] D. C. Montgomery, Design and Analysis of Experiments, John Wiley \& Sons, Hoboken, NJ, USA, 8th edition, 2017.

[32] V. D. Zheljazkov, B. A. Vick, B. S. Baldwin, N. Buehring, T. Astatkie, and B. Johnson, "Oil content and saturated fatty acids in sunflower as a function of planting date, nitrogen rate, and hybrid," Agronomy Journal, vol. 101, no. 4, pp. 1003-1011, 2009.

[33] Environment Canada, "Nova scotia, Canada- sunrise, sunset and day length," 2018, https://www.timeanddate.com/sun/ canada/halifax.

[34] S. Thamburaj and N. Singh, "Textbook of vegetables, tuber crops and spices," in Leafy and Salad Vegetables, pp. 359-443, Indian Council of Agricultural Research, New Delhi, India, 5th edition, 2005. 
[35] W. F. Whitehead, J. Carter, and B. P. Singh, "Effect of planting date on vegetable amaranth leaf yield, plant height, and gas exchange," HortScience, vol. 37, no. 5, pp. 773-777, 2002.

[36] A. M. Opiyo, "Effect of nitrogen application on leaf yield and nutritive quality of black nightshade (solanum NigrumL.)," Outlook on Agriculture, vol. 33, no. 3, pp. 209-214, 2004.

[37] Z. Wang and S. Li, "Effects of nitrogen and phosphorus fertilization on plant growth and nitrate accumulation in vegetables," Journal of Plant Nutrition, vol. 27, no. 3, pp. 539-556, 2004.

[38] J. N. E. Frota and T. C. Tucker, "Temperature influence on ammonium and nitrate absorption by lettuce," Soil Science Society of America Journal, vol. 36, no. 1, pp. 97-100, 1972.

[39] M. Razaq, P. Zhang, and H.-1. Shen, "Influence of nitrogen and phosphorous on the growth and root morphology of Acer mono," PLoS One, vol. 12, no. 2, Article ID e0171321, 2017.

[40] B. Bojovic and J. Stojanovic, "Chlorophyll and carotenoid content in wheat cultivars as a function of mineral nutrition," Archives of Biological Sciences, vol. 57, no. 4, pp. 283-290, 2005.

[41] M. B. Ali, L. Khandaker, and S. Oba, "Comparative study on functional components, antioxidant activity and color parameters of selected colored leafy vegetables as affected by photoperiods," Journal of Food, Agriculture and Environment, vol. 7, pp. 392-398, 2009.

[42] S. L. Gulmon and C. C. Chu, "The effects of light and nitrogen on photosynthesis, leaf characteristics, and dry matter allocation in the chaparral shrub, Diplacus aurantiacus," Oecologia, vol. 49, no. 2, pp. 207-212, 1981.

[43] J. Sorensen, "Nitrogen effects on vegetable crop production and chemical composition," Acta Horticulturae, vol. 506, no. 506, pp. 41-50, 1999.

[44] M. T. Salahuddin, H. Begum, N. Sunil, P. S. Rao, N. Sivaraj, and S. Kumar, "Preliminary characterization and evaluation of landraces of Indian spinach (Basella spp. L.) for agroeconomic and quality traits," Plant Breeding and Biotechnology, vol. 2, no. 1, pp. 48-63, 2014.

[45] C. Bénard, H. Gautier, F. Bourgaud et al., "Effects of low nitrogen supply on tomato (Solanum lycopersicum) fruit yield and quality with special emphasis on sugars, acids, ascorbate, carotenoids, and phenolic compounds," Journal of Agricultural and Food Chemistry, vol. 57, no. 10, pp. 4112-4123, 2009.

[46] A. Marin, F. Ferreres, G. G. Barberá, and M. I. Gil, "Weather variability influences color and phenolic content of pigmented baby leaf lettuces throughout the season," Journal of Agricultural and Food Chemistry, vol. 63, no. 6, pp. 1673-1681, 2015.

[47] P. Maisuthisakul, M. Suttajit, and R. Pongsawatmanit, "Assessment of phenolic content and free radical-scavenging capacity of some Thai indigenous plants," Food Chemistry, vol. 100, no. 4, pp. 1409-1418, 2007.

[48] F. M. Oloyede, F. A. Oloyede, and E. M. Obuotor, "Comparative studies of chemical compositions of two species of Basella," Applied Scientific Reports, vol. 3, pp. 121-124, 2013.

[49] K. D. P. P. Gunathilake and K. K. D. S. Ranaweera, "Antioxidative properties of 34 green leafy vegetables," Journal of Functional Foods, vol. 26, pp. 176-186, 2016.

[50] M. Blom-Zandstra, "Nitrate accumulation in vegetables and its relationship to quality," Annals of Applied Biology, vol. 115, no. 3, pp. 553-561, 1989. 